\title{
REVISIÓN DEL SISTEMA PRONOMINAL ESPAÑOL
}

\author{
FCO. JAVIER SATORRE GRAU \\ Universidad de Valencia
}

Con este trabajo pretendo realizar una revisión critica del sistema pronominal español (pronombres personales, posesivos y demostrativos) tomando como punto de partida los textos de Nebrija y de los gramáticos de los siglos xvi y xvi. La lectura de estos textos nos permite observar que, con frecuencia, la historia de la gramática es una historia de errores. Son, fundamentalmente, las conveniencias metodológicas de los gramáticos, que pretenden ofrecer unos modelos regulares, las que los obligan muchas veces a falsear la realidad de la lengua. Suele ocurrir también que, cuando estos autores pretenden madurar el pensamiento gramatical desarrollando ciertas categorías o estableciendo divisiones dentro de ellas, crean errores que se perpetúan en las páginas de sus textos gramaticales. Esto es, en mi opinión, lo que ha ocurrido en el caso del pronombre.

1. El paradigma pronominal que ofrece Nebrija en su Gramática Castellana ${ }^{1}$ está condicionado por la definición que da de dicha categoría:

E llámase pronombre por que se pone en lugar de nombre proprio, por que tanto vale io como Antonio, tú como Hernando (pág. 180).

Pronombre es, según esto, la palabra por medio de la cual podemos hacer referencia a una persona. Según el gramático andaluz, seis son las formas gramaticales que cumplen las condiciones requeridas para ser consideradas como pronombres:

Las especies del pronombre son dos, como diximos del nombre: primogénita \& derivada. De la especie primogénita son seis pronombres: io, tú,

\footnotetext{
1 A. de Nebrija, Gramática de la lengua castellana (1492), estudio y edición de A. Quilis, Madrid, Editora Nacional, 1981, pág. 180.
}

RFE, LXXXII, 2002, $3 .^{\circ}-4 .^{\circ}$, págs. $345-380$ 
si, este, esse, él. De la especie derivada son cinco: mio, tuio, suio, nuestro, vuestro. \& tres cortados: de mio, mi; de tuio, tu; de suio, su. Las fjguras del pronombre son dos: assí como en el nombre: simple \& compuesta. Simple como este, esse, él. Compuesta como aqueste. aquesse. aquel. (pág. 180)

Llama la atención la inclusión de todas estas formas en la misma categoría de "pronombres", dividida en dos partes por razones puramente genéticas: unas son primitivas y las otras se derivan de las primeras ${ }^{2}$. Pero no hay una diferencia radical entre ellas que nos permita interpretar que Nebrija las consideraba como formando parte de clases distintas. Podemos representar el sistema pronominal postulado por Nebrija por medio del siguiente esquema:

\begin{tabular}{|c|c|c|c|c|c|c|c|}
\hline \multirow[t]{2}{*}{ Primogénitos } & Simples & $\overline{y o}$ & tú & si & este & ese & 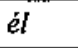 \\
\hline & Compuestos & . & & & aqueste & aquese & aquel \\
\hline \multirow[t]{2}{*}{ Derivados } & Plenos & $\begin{array}{l}\text { mio } \\
\text { nuestro }\end{array}$ & $\begin{array}{l}\text { tuyo } \\
\text { vuestro }\end{array}$ & stuyo & & & \\
\hline & Cortados & $m i$ & $t u$ & $s u$ & & & \\
\hline
\end{tabular}

En la exposición de su teoría gramatical sobre el pronombre, así como en el conjunto de su obra sobre la lengua castellana, se puede rastrear claramente el modelo gramatical latino que él mismo había dejado escrito en sus Introductiones latinae ${ }^{3}$. Así, este modelo latino se reconoce, tanto en la definición de la categoría:

Pronomen est pars orationis declinabilis quae pro nomine proprio cuiusque accipitur: personasque finitas recipit. (fol 23r.)

como en la descripción y clasificación del paradigma pronominal:

Species pronominum duae sunt: primigenia et deriuatiua. Primigeniae octo sunt pronomina: ego. tu. sut. hic. iste. ille. ipse. is. Deriuatiuae septem: a genitiuo mei, mets, a, um; a genitiuo tui, tuus, a, tuum; a genitiuo sui, suus, a, um; a genitiuo nostri, noster, nostra, nostrum, nostras, tis; a genitiuo uestri, uester, uestra, uestrum, uestras, uestratis. Genera pronominum quinque sunt: masculinum ut meus; foemininum ut mea; neutrum ut meum. Commune duorum generum, ut hic et haec nostras, hic et haec

\footnotetext{
2 "Tanto en Dionisio de Tracia como en Prisciano encontramos una distinción que posteriormente cobrará fortuna: aquella que distingue entre pronombres primitivos y derivados". A. Ramajo Caño, Las gramáticas de la lengua castellana desde Nebrija a Correas, Universidad de Salamanca, 1987 , pág. 127. 1981 .

${ }^{3}$ A. de Nebrija, Introductiones latinae (Salamanca, 1481), edición facsimilar, Salamanca,
} 
uestras; quae uerius communia trium generum esse dicendum est, sicut ego, $t u$, genitiuo sui. Numeri pronominum sicut et nominum duo sunt: singularis ut $e g o, t u$; pluralis ut nos, uos. Figurae pronominum duae sunt: simplex, ut hic, iste; composita, ut isthic, isthuc. Componuntur autem pronomina cum nomine, ut eiuscemodi, huiusmodi, et cum altero pronomine, ut me me, te te, et cum aduerbiis, ut eccum ellum, cum praepositione, ut mecum, tecum, secum, nobiscum. (fol 23v.)

Según el texto nebrisense, el paradigma pronominal latino se podría representar por medio del esquema siguiente:

\begin{tabular}{|l|l|l|l|l|l|l|l|l|l|}
\hline Primogénitos & Simples & $\begin{array}{l}\text { ego } \\
\text { nos }\end{array}$ & $\begin{array}{l}\text { th } \\
\text { uos }\end{array}$ & sui & hic & iste & ille & ipse & is \\
\cline { 2 - 7 } & Compuestos & $\begin{array}{l}\text { meme } \\
\text { mecum } \\
\text { nobiscum }\end{array}$ & $\begin{array}{l}\text { tete } \\
\text { tecum }\end{array}$ & secum & $\begin{array}{l}\text { isthic } \\
\text { huiusmodi }\end{array}$ & $\begin{array}{l}\text { isthuc } \\
\text { Deccum } \\
\text { ellum }\end{array}$ & $\begin{array}{l}\text { eiusce- } \\
\text { modi }\end{array}$ \\
\hline Derivados & $\begin{array}{l}\text { meus } \\
\text { noster }\end{array}$ & $\begin{array}{l}\text { tus } \\
\text { vester }\end{array}$ & suus & & & & & \\
\hline
\end{tabular}

Si se comparan estos dos modelos pronominales, se pueden observar claras diferencias:

a) La lengua castellana, en Nebrija, tiene un paradigma pronominal más reducido que la lengua latina: los pronombres primogénitos simples latinos son ocho, frente a los seis castellanos. IPSE e IS no tienen formas correspondientes en el paradigma castellano nebrisense. La forma mismo no merece en Nebrija la misma consideración que IPSE. Según él, se trata simplemente de un elemento enfático que se debe adjuntar a otro pronombre.

b) El latín ofrece mayor posibilidad de formar compuestos pronominales que el castellano, combinando la forma pronominal con nombres (HUIUSMODI, EIUSCEMODI), otros pronombres (MEME, TETE), adverbios (ECCUM ILLE; ISTHIC, ISTHUC) o preposiciones (MECUM, TECUM, SECUM...).

c) Los pronombres derivados latinos no tienen formas apocopadas.

Pero ello no es óbice para reconocer una semejanza notoria entre ellos. El esquema gramatical latino ha servido de modelo para el modelo castellano, aunque éste es manifiestamente más reducido.

En las. Introductiones, cuando proporciona la relación de formas adverbiales latinas, incluye Nebrija unos adverbia personalia, grupo constituido por las formas MECUM, TECUM Y SECUM. Esto no tiene correspondencia en su Gramática castellana, obra en la que no se hace mención a los equiva- 
lentes castellanos conmigo, contigo y consigo. Sin embargo, la consideración adverbial de los compuestos resultantes de la adjunción de la preposición CUM a los pronombres personales aflorará en las gramáticas de la lengua española de los siglos XVI y XVII. Así, por ejemplo, conmigo, contigo y consigo aparecen como adverbios de persona en el anónimo de Lovaina de $1555^{4}$. Miranda, en el libro tercero de sus Osservationi, dedicado al adverbio, incluye un apartado en el que habla de los "avverbi di persone", en los que registra los adverbios comigo, contigo, consigo, equivalentes a los italianos meco, teco, seco ${ }^{5}$. Conducta semejante adopta César Oudin, quien habla de estas formas como "aduerbes personnels" en el capítulo dedicado al adverbio, haciéndolos equivaler a las expresiones francesas avec moy, avec toy, avec soy ${ }^{6}$. Ya bien entrado el siglo xvII, Franciosini sigue hablando de comigo, contigo, consigo como "auuerbi personali e che significano compagnia" 7 .

En la gramática nebrisense puede reconocerse, por tanto, un modelo de formas pronominales que se podría representar por el esquema siguiente:

\begin{tabular}{|l|l|l|l|l|l|l|l|}
\hline \multirow{2}{*}{ Primogénitos } & Simples & $y o$ & tú & sí & este & ese & $\dot{e l}$ \\
\cline { 2 - 8 } & Compuestos & & & & aqueste & aquese & aquel \\
\hline \multirow{2}{*}{ Derivados } & Plenos & $\begin{array}{l}\text { mio } \\
\text { nuestro }\end{array}$ & $\begin{array}{l}\text { tuyo } \\
\text { vuestro }\end{array}$ & stuyo & & & \\
& Cortados & $m i$ & $\overline{t u}$ & su & & & \\
\hline Adverbios & & conmigo & contigo & consigo & & & \\
\hline
\end{tabular}

2. Este modelo pronominal ha experimentado, a lo largo de la historia de la gramática, modificaciones radicales que podemos resumir de la siguiente manera:

a) División del paradigma único de pronombres en tres paradigmas pronominales diferentes, sin relación aparente entre sí: pronombres personales, pronombres demostrativos y pronombres posesivos. Cada uno de estos paradigmas cuenta con su elenco de formas pronominales exclusivas.

${ }^{4}$ Vtil y breve institutión para aprender los principios y fundamentos de la lengua hespañola, Lovaina, 1555, Ed. facsimilar con estudio e índice de A. Roldán, Madrid, CSIC, 1977, pág. 107.

${ }^{5} \mathrm{G}$. Miranda, Osservationi della lingua castigliana, edición y estudio de J. M. Lope Blanch, México, UNAM, 1998, pág. 268.

${ }^{6}$ C. Oudin, Grammaire espagnolle expliquee en françois, Paris, 1597. Cito por la edición de París, 1660. (BN de Madrid, R/31202), pág. 179.

L. Franciosini, Grammatica spagnuola ed italiana, Roma, 1638 (BN de Madrid, 3/33673), pág. 135 . 
b) Para la confección de estos tres paradigmas pronominales, se han tenido que realizar desplazamientos de determinadas formas para completar el modelo gramatical latino, que se manifestaba, en algún caso, claramente defectivo. En todas las ocasiones, los derivados románicos del demostrativo latino ILLE, en diversas formas flexivas, invaden los huecos existentes en los paradigmas pronominales, tanto personales como posesivos, además de crear categorías gramaticales nuevas en las lenguas románicas, que el latín desconocía, como es el caso del artículo: - El, ella, ello, ellos, ellas pasan a ser las formas rectas del pronombre personal de tercera persona (en sus paradigmas reflexivo y no reflexivo), debido a que este pronombre personal latino no tenía forma correspondiente al caso nominativo. Estas mismas formas son las que tiene el llamado pronombre personal de tercera persona no reflexivo cuando desempeña las funciones de complemento tónico término de preposición.

- El lugar dejado vacante por él, ella, ello, en el paradigma de los demostrativos es ocupado por las formas compuestas aquel, aquella, aquello. Las formas compuestas aqueste y aquese desaparecen por falta de uso. Deja de haber, pues, un paradigma doble de pronombres demostrativos, uno de formas simples y uno de formas compuestas; sólo hay uno, constituido por las formas simples este y ese y por la forma compuesta aquel.

- Las formas le, les, procedentes de los dativos del demostrativo latino ILLI, ILLIS, y $l o$, la, y sus respectivos plurales, los, las, que tienen su origen en los acusativos ILLUM, ILLAM e ILLOS, ILLAS respectivamente, son considerados pronombres personales clíticos de tercera persona y conservan las funciones etimológicas de $\mathrm{Cl}$ y CD.

- En muchas lenguas románicas, la forma derivada de ILLORUM, genitivo plural de ILLE, se desplaza hasta el paradigma posesivo, para ocupar la casilla del posesivo de varios poseedores de tercera persona (francés leur; italiano loro, catalán llur, etc.).

c) Las formas adverbiales conmigo, contigo y consigo se consideran como formas pronominales no adverbiales.

d) El pronombre si se iguala, en cuanto a su consideración gramatical, con las formas $m i$ y $t i$, pronombres tónicos preposicionales de primera y segunda personas. Una asociación de naturaleza semejante se produce entre los pronombres átonos $m e$, te y $s e$.

e) Los tres paradigmas pronominales (personales, demostrativos y posesivos) están caracterizados, según la mayor parte de los gramáticos, por tener morfema de persona. 
Podemos esquematizar esta serie de cambios por medio de los siguientes cuadros sinópticos:

Pronombres personales:

Singular:

\begin{tabular}{|c|c|c|c|c|}
\hline & 1. ${ }^{a}$ persona & 2." persona & 3. ${ }^{a}$ persona reflex. & 3., persona no reflex. \\
\hline Sujeto & yo & tú & él, ella, ello & \multirow[b]{2}{*}{ él, ella, ello } \\
\hline $\begin{array}{l}\text { Complemento tónico } \\
\text { preposicional }\end{array}$ & $\begin{array}{l}\text { mi } \\
\text { conmigo }\end{array}$ & $\begin{array}{l}t i \\
\text { contigo }\end{array}$ & $\begin{array}{l}\text { sí } \\
\text { consigo }\end{array}$ & \\
\hline Complem. átono CD & \multirow[t]{2}{*}{$m e$} & \multirow[t]{2}{*}{ te } & \multirow[t]{2}{*}{ se } & la, lo \\
\hline Complem. átono CI & & & & le \\
\hline
\end{tabular}

Plural:

\begin{tabular}{|c|c|c|c|c|}
\hline & 1. persona & 2.a persona & 3. persona reflex. & 3. ${ }^{\mathrm{a}}$ persona no reflex. \\
\hline Sujeto & \multirow{2}{*}{$\begin{array}{l}\text { nosotros } \\
\text { nosotras }\end{array}$} & \multirow{2}{*}{$\begin{array}{l}\text { vosotros } \\
\text { vosotras }\end{array}$} & ellos, ellos & \multirow[b]{2}{*}{ ellos, ellas } \\
\hline $\begin{array}{l}\text { Complemento tónico } \\
\text { preposicional }\end{array}$ & & & $\begin{array}{l}\text { si } \\
\text { consigo }\end{array}$ & \\
\hline Complem. átono $\mathrm{CD}$ & \multirow[t]{2}{*}{ nos } & \multirow[t]{2}{*}{ os } & \multirow[t]{2}{*}{ se } & las, los \\
\hline Complem. átono CI & & & & les \\
\hline
\end{tabular}

Pronombres demostrativos:

\begin{tabular}{|l|l|}
\hline 1." persona & este, esta, esto, estos, estas \\
\hline 2." persona & ese, esa, eso, esos, esas \\
\hline 3. ${ }^{\text {a }}$ persona & aquel, aquella, aquello, aquellos, aquellas \\
\hline
\end{tabular}

Pronombres posesivos:

Un poseedor:

\begin{tabular}{|l|l|}
\hline 1. ${ }^{a}$ persona & mio, mia, mios, mias / mi, mis \\
\hline 2. persona & tuyo, tuya, tuyos, tuyas / tu, tus \\
\hline 3. persona & suyo, suya, suyos, suyas / su, sus \\
\hline
\end{tabular}

Varios poseedores:

\begin{tabular}{|l|l|}
\hline $1 .^{\text {a }}$ persona & nuestro, nuestra, nuestros, nuestras \\
\hline 2." persona & vuestro, vuestra, vuestros, vuestras \\
\hline 3." persona & suyo, suya, suyos, suyas / su, sus \\
\hline
\end{tabular}


Éste es, grosso modo, el sistema pronominal que ha transmitido nuestra tradición gramatical, y que sigue vigente en la mayor parte de las gramáticas españolas en la actualidad.

3. Sin embargo, el resultado es, desde el punto de vista de la teoría gramatical, enormemente discutible.

a) ¿Por qué se acepta, sin discusión previa, este desplazamiento de los demostrativos a áreas categorialmente diferentes? ¿Lo que era un demostrativo se convierte en un pronombre personal o en un posesivo, sin más? ¿Abandona totalmente la categoria gramatical de origen para ingresar en la nueva, adoptando por completo otra naturaleza? ¿Realmente los demostrativos él, ella, ello, le, la, lo y sus plurales se cargan de significado personal?

b) Las tres series de formas, el, la, lo; él, ella, ello; le, la, lo, que tienen su origen en el demostrativo latino ILLE, ILLA, ILLUD, ipierden toda vinculación con la categoría de los demostrativos de la que proceden, o siguen conservando, con alguna variación, la naturaleza gramatical originaria?

c) ¿Puede admitirse que los demostrativos están caracterizados gramaticalmente por la presencia del morfema de persona? Si la respuesta es negativa, ¿puede aceptarse que los demostrativos que, supuestamente, se desplazan al paradigma de los pronombres personales adquieren, en este movimiento, el morfema de persona del que carecen?

d) ¿Se pueden igualar desde el punto de vista categorial las formas me, $t e$ con la forma $s e$ ? ¿Las formas $m i$, $t i$ con la forma $s i$ ? ¿La analogía formal es argumento suficiente para realizar esta igualación?

e) ¿Es legítima la separación categorial de los posesivos con respecto a los pronombres personales?

Vamos a ir intentando dar respuesta a todos estos interrogantes.

4. Es necesario definir con precisión qué se entiende por persona gramatical para no caer en equívocos. La palabra persona, desde el punto de vista etimológico, significa "máscara de actor", "personaje". Podemos admitir este valor cuando hablamos de personas gramaticales, porque son los papeles que desempeñan los participantes en el acto de hablar. Cuando el participante hace uso de la palabra, desempeña el papel del emisor y, entonces, se refiere a sí mismo por medio de las formas gramaticales de primera persona, mientras que hace referencia a su interlocutor por medio de las formas gramaticales de segunda persona. Este mismo participante, cuando cede el uso de la palabra a su interlocutor, pasa a desempeñar el papel de receptor $y$, 
entonces, es designado por las formas de segunda persona, en tanto que la primera persona hace referencia al que está hablando. Las personas gramaticales son, pues, los participantes en el coloquio, de manera que sólo hay dos personas: el que babla (primera persona) y su interlocutor (segunda persona). La persona gramatical está vista siempre desde la perspectiva del que hace uso de la palabra, de manera que yo, mi, me, mio o canto son las formas que emplea el emisor del mensaje para referirse a sí mismo, mientras que utiliza $t \dot{u}, t i$, te, tuyo o cantas para señalar a aquel a quien se dirige.

Pero el concepto de persona podemos entenderlo también en su sentido antropológico, como ser racional inteligente ${ }^{8}$. La persona gramatical, que es un morfema (unidad mínima de significado gramatical) que se manifiesta a través de unos morfos determinados, señala siempre a entes personales. El que habla siempre tiene que ser un ser personal, es decir, debe ser capaz de hacer uso de la palabra. Del mismo modo, la segunda persona siempre debe tener la capacidad de recibir el menśaje, de entenderlo y de convertirse en primera persona cuando tome el turno de palabra; los dos participantes del coloquio hacen uso de la palabra, de manera que, siempre y en todas las ocasiones, tanto la primera como la segunda personas se refieren a entes personales.

Lo que no es el hablante o el interlocutor, es decir, todo lo demás, lo que no es primera o segunda persona, es no-persona ${ }^{9}$. A esta no-persona la tradición gramatical la ha denominado "tercera persona". Las marcas flexivas de esta no-persona se emplean cuando el hablante se refiere a algo distinto de él mismo o de su interlocutor, para hablar del resto del universo, de todas las cosas que constituyen el mundo de su experiencia, entre las que, claro está, puede haber también seres personales ${ }^{10}$.

La tradición gramatical grecolatina define la tercera persona como aquella de la que se habla, o más concretamente, aquella de la que habla la primera persona. Así la define Dionisio de Tracia, y entre los latinos, Diomedes, Consentio y Prisciano ${ }^{11}$. Esta tradición la recoge Nebrija en sus Introductiones de este modo:

\footnotetext{
${ }^{8}$ Diomedes define la persona como substantia rationalis. Cita tomada de A. Ramajo Caño, Las gramáticas de la lengua castellana..., op. cit., pág. 167.

${ }^{9}$ E. Benveniste, Problemas de lingüística general, México, Siglo XXI, 1972, pág. 171.

${ }^{10}$ Una definición como la que da C. Muñoz en "Los pronombres personales", en M. Siguán (coord.), Estudios de psicolingüística, Madrid, Pirámide, 1986, pág. 117: "el pronombre de tercera persona corresponde al rol del que no interviene en el acto lingüístico", me parece insuficiente por parcial. El que no interviene en el acto lingǘístico es tercera persona, al igual que todo lo que no es emisor ni receptor, sea personal o no.

"A. Ramajo Caño, Las gramáticas de la lengua castellana..., op. cit., págs. 166 y 167.

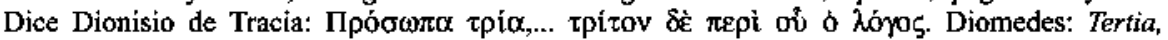
de qua quis loquitur et relatio indicatur. Consentio: tertia, de qua dicitur. Prisciano: tertia, de qua extra se et illam, ad quam dirigit sermonem, posita loquitur prima.
} 
Personae uerborum tres sunt: prima, secunda, tertia. Prima quae de se sola uel de se cum aliis loquitur, ut ego amo, nos amamus. Secunda ad quam solam uel cum aliis prima loquitur, ut tu amas, uos amatis. Tertia de qua sola uel de quibus prima loquitur, ut Cicero legit, homines legunt (fol 19r.).

Esta definición me parece muy peligrosa, porque da cabida a interpretaciones erróneas, como es la de pensar que la tercera persona está implicada en la primera y en la segunda, ya que, cuando el hablante dice yo, habla de alguien, por lo tanto la primera persona es, al mismo tiempo, primera y tercera persona; esto mismo se podría decir de la segunda persona, que sería, al mismo tiempo, segunda y tercera ${ }^{12}$.

5. La identificación de la persona gramatical con los partícipes del acto comunicativo lleva consigo la aceptación de tan sólo dos personas gramaticales: yo y $t u$, primera y segunda persona respectivamente. Sus plurales, nosotros y vosotros, como ya se ha observado en repetidas ocasiones ${ }^{13}$, significan persona gramatical solamente en la medida en la que incluyen en su significación al emisor y al receptor ${ }^{14}$. Pero hay profundas diferencias entre la primera y segunda personas stricto sensu, y sus plurales correspondientes:

a) Cualquier sustantivo o pronombre que incluya en su extensión designativa al emisor puede establecer relación de concordancia con el verbo en primera persona del plural. Por eso pueden ser sujetos de verbos en primera persona del plural -junto a nosotros, que siempre exige esta concordancia- otros pronombres o sustantivos como en los ejemplos siguientes:

\section{Algunos hemos venido de buena fe \\ Los profesores tenemos mucho trabajo \\ Los morenos resistimos mejor el sol}

${ }^{12}$ Es lo que hace, por ejemplo, G. Luquet, "Modos y persona en la historia del verbo español", en Actas del V Congreso Internacional de Historia de la Lengua Española, I, Madrid, Gredos, 2002, págs. 757-758.

${ }^{13}$ E. Alarcos hace mención de ello en "Los pronombres personales", en Estudios de gramática funcional del español, Madrid, Gredos, 1978, pág. 152, nota: "Para abreviar llamaremos plural lo indicado por /nosotros/, etc., aunque en realidad no signifique «varias primeras personas», sino «primera persona + otras personas no primera)". A este tema dedica Luis J. Prieto su trabajo titulado "Una nota de gramática: «nosotros», iplural de «yo)?", en Estudios ofrecidos a Emilio Alarcos Llorach, I, Oviedo, Universidad de Oviedo, 1976, págs. 209-216. También J. L. Rivarola, "¿Quién es nosotros", en Estudios de lingüística. Universidad de Alicante, 2, 1984, págs. 201-206.

${ }_{14}$ No estoy de acuerdo con lo que expone R. Almela Pérez en su artículo " ¿Es nosotros el plural de yo?", en Estudios de lingüistica. Universidad de Alicante, 14, 2000, págs. 9-17. Para este autor yo es el hablante indiviso, en tanto que nosotros es el hablante diviso (pág. 10). Tampoco estoy de acuerdo con el concepto de número de este autor, ya que establece la misma oposición singular/plural entre yo / nosotros que entre tzyo / vuestro (págs. 12, 16). El plural es un morfema concordante; el piural de tuyo es tuyos, no vuestro. 
Del mismo modo, puede establecer relación de concordancia con el verbo en segunda persona del plural cualquier sustantivo o pronombre que incluya en su extensión designativa al receptor. Vosotros es el pronombre que, de manera especifica y exclusiva, significa un conjunto de elementos entre los que se incluye el receptor. Pero, como en el caso anterior, también otros pronombres y sustantivos pueden establecer una relación de concordancia en segunda persona del plural con el verbo:

Algunos habéis venido de buena fe

Los profesores tenéis mucho trabajo

Los morenos resistís mejor el sol

Es interesante notar que el conjunto en el que se integra el emisor en la primera persona del plural, o aquel en el que se integra el receptor en la segunda del plural no tiene por qué estar constituido necesariamente por elementos personales. Lo único necesario es que el emisor o el receptor estén incluidos en dicho conjunto:

Todos los seres de la creación tenemos nuestro lugar en este mundo El árbol que hay en el jardin y yo hemos crecido juntos

El árbol que hay en el jardin y tú habéis crecido juntos

b) Los plurales nosotros/nosotras, vosotros/vosotras tienen marcas flexivas de género, debido a su naturaleza compuesta de nos/vos + otros, as, cosa que no ocurre con los pronombres personales yo/tú.

c) Yo y tú son pronombres deícticos transparentes, es decir, conocemos su significado $\sin$ tener que recurrir al contexto. Siempre señalan al emisor y al receptor ${ }^{15}$. En cambio, nosotros y vosotros son deícticos

\footnotetext{
15 La gramática antigua constató esta diferente manera de significar de los pronombres. A. M. ${ }^{a}$ Barrenechea observa que ya los griegos distinguieron entre el valor deíctico de unos pronombres frente al valor anafórico de otros, distinción que en el Renacimiento sigue viva en autores como Escalígero o el Brocense. ("El pronombre y su inclusión en un sistema de categorías sernánticas", en A. M. Barrenechea y M. Manacorda de Rosetti, Estudios de grumática estructural, Buenos Aires, Paidós, 1979, págs. 27). Nuestros gramáticos del Siglo de Oro establecieron una nítida diferencia entre pronombres "demostrativos" y pronombres "relativos", según se emplearan para referirse a objetos presentes o para remitir a un objeto antes mencionado. Los pronombres yo, tú ser̃alan a las personas presentes en el acto de comunicación -emisor y receptor-; en tanto que ta llamada tercera persona -lo que no es ni emisor ni receptor- puede o no estar presente en dicho acto de comunicación. De esta manera, para nuestros gramáticos clésicos, yo y tú son pronombres "demostrativos", mientras que él, aquel, etc. son pronombres "demostrativos y relativos". Dice A. Ramajo Caño, Las gramáticas de la lengua castellana desde Nebrija a Correas, op. cit., págs. 128-129: "La tercera persona plantea delicados problemas, pues no presenta la determinación de la primera o de la segunda, presentes en el acto de la comunicación. Estas dos son siempre demostrativas, en tanto que aquélla, ya es demostrativa, ya relativa... La tercera persona no indica, pues, concreción en sí misma; de aquí
} 
parcialmente opacos. Lo único que sabemos de su significación es que en el colectivo por ellos designado se incluye el emisor o el receptor. El resto ha de proporcionarse textual o situacionalmente. Por eso es posible conocer el valor designativo de nosotros o de vosotros por medio de referencias anafóricas o catafóricas, cosa que es absolutamente imposible en el caso de yo o de tú.

d) Es manifiestamente diferente la flexión casual de estos pronombres. Nosotros y vosotros desempeñan las funciones correspondientes a los singulares $y o / m i$ y $t \dot{u} / t i$, respectivamente. Los plurales no tienen una forma específica para las funciones en las que son término de preposición. Además, las formas clíticas (nos, os) son simples, frente a las que desempeñan las funciones de sujeto o de complemento término de preposición (nosotros, vosotros), que son compuestas

\begin{tabular}{|c|c|c|c|c|}
\hline & \multicolumn{2}{|l|}{ Singular } & \multicolumn{2}{|l|}{ Plural } \\
\hline & $1 .^{2}$ persona & 2. ${ }^{a}$ persona & 1. persona & 2." persona \\
\hline Sujeto & yo & $t \dot{u}$ & \multirow{2}{*}{$\begin{array}{l}\text { nosotros } \\
\text { nosotras }\end{array}$} & \multirow{2}{*}{$\begin{array}{l}\text { vosotros } \\
\text { vosotras }\end{array}$} \\
\hline $\begin{array}{l}\text { Complemento tónico } \\
\text { preposicional }\end{array}$ & $m i$ & $t i$ & & \\
\hline Complem. átono & $m e$ & te & nos & os \\
\hline
\end{tabular}

Resumiendo: es legitimo incluir entre los pronombres personales las formas plurales nosotros/nos, vosotros/os, porque siempre incluyen en su extensión designativa al emisor y al receptor, aun teniendo en cuenta las grandes diferencias que los separan de los pronombres $y o / m i / m e, ~ t u ́ t i / t e$, que significan exclusivamente las personas gramaticales, es decir, el emisor y el receptor.

6. El latín sólo tenía, en sentido estricto, pronombres personales de primera y de segunda personas. Las formas SUI, SIBI, SE, idénticas para el singular y para el plural, pertenecían a un paradigma de pronombres reflexivos, carente de forma en caso nominativo. Para referirse a lo que no es ni emisor ni receptor, el latín empleaba el pronombre anafórico is o algún demostrativo ${ }^{16}$. Sin embargo, la necesidad que tienen los gramáticos de clasificar, de crear paradigmas ligados por relaciones de analogía, fue la causa de que, desde épocas muy tempranas, se emparentaran las formas genitivas MEI / TUI / SUI; las dati-

que para expresar toda su riqueza necesite diversos pronombres, que indicarán cercania, en unos cașos, lejania. en otros; que señalarán directamente a una persona o cosa (demonstrativa pronomina) o, antes bien, se referirán a ella (relativa pronomina): EGO señala, IS remite a alguien".

${ }_{16}$ Véase A. Enout et F. Thomas, Syntaxe latine, París, Klincksieck, 1993, pág. 179; M. Bassols de Climent, Sintaxis Latina, I, Madrid, CSIC, 1976, págs. 188-190. 
vas MIHI / TIBI / SIBI; y las acusativas y ablativas ME / TE / SE, de manera que del reconocimiento de la semejanza formal se pasó a la igualación categorial.

En este aspecto, la situación que presenta el español en la actualidad es prácticamente idéntica a la que tenía el latín. El paradigma formado por los reflexivos sí, se, consigo carece de una forma pronominal capaz de desempeñar la función de sujeto, por lo que tiene que recurrir, como hacía el latín, a los demostrativos él, ella, ello o a otras formas pronominales. Además, son formas que no presentan variación morfemática de número. A pesar de ello, ya Nebrija, en sus Introductiones, no establece diferencia categorial entre los pronombres de primera y segunda personas y el pronombre reflexivo. La práctica totalidad de los gramáticos castellanos antiguos propone en sus textos un pronombre personal de tercera persona formado por si (en ocasiones precedido por distintas preposiciones) y $s e^{17}$.

Sin embargo, nadie parece reparar en el hecho de que se no se comporta de manera semejante a como lo hacen me y te. Estos últimos pronombres admiten empleos reflexivos y no reflexivos, mientras que se admite única y exclusivamente los usos reflexivos, como sucedía ya con sus étimos latinos:

Me veo / me ves / me ve

Te veo / te ves / te ve

*Se veo / *se ves / se ve

El pronombre reflexivo no es un pronombre personal porque nunca hace referencia ni al emisor ni al receptor. No debe extrañarnos que, frecuentemente, se emplee para indicar impersonalidad:

Se dice que bajarán los precios

En España se vive bien

o para expresar diferentes valores diatéticos verbales; así por ejemplo, expresiones como:

Se ha soltado el asa

Se ha hundido el techo

adquieren un valor medio $\mathrm{y}$ otras como:

La aceituna se recoge en invierno

Los exámenes se realizan en junio

tienen sentido pasivo.

17 Esto es lo que hacen, por ejemplo, Nebrija, pág. 235, Lovaina 1555, pág. 28, Lovaina 1559, pág. 40, Miranda, pág. 86, A. del Corro, pág. 36, Percyvall, pág. 16, Charpentier, fol, 43r., Oudin, p, 33, Minsheu, pág. 17, Fray Diego de la Encarnación, pág. 61, Franciosini, pág., 23, Correas, Arte. pág. 161; Trilingüe, pág. 30, Fabre, pág., 28, Sumarán, Thesaurus, pág. 87; Grammatica, pág. 77 y Mulerio, pág. 9. 
Además, un rasgo importante de diferenciación entre los pronombres personales y el reflexivo que presentaba la lengua latina, y que se mantiene en español, consiste en que éste tiene la misma forma para el singular y para el plural, mientras que los pronombres personales tienen formas diferentes:

Se peina / Se peinan

Me peino / Nos peinamos / Te peinas / Os peináis

La lengua española mantiene un sistema de pronombres reflexivos que, como en latín, tiene idénticas formas en singular y en plural, y que carece de forma nominativa. El español no dispone de un pronombre reflexivo que pueda desempeñar la función de sujeto. Recurre, para realizar esta función, a otros pronombres o a sustantivos. El paradigma de pronombres reflexivos españoles puede representarse por el siguiente esquema:

\begin{tabular}{|l|l|}
\hline & Pronombre refiexivo singular y plural \\
\hline Sujeto & \\
\hline Complemento tónico preposicional & si \\
\hline Complemento átono, no preposicional & se \\
\hline
\end{tabular}

7. Un factor de importancia decisiva en el proceso de creación de un paradigma de pronombres personales integrado por formas heterogéneas es el ejercido por la conjugación verbal. El verbo presenta unas formas flexivas diferentes (AMO, AMAS, AMAT, AMAMUS, AMATIS, AMANT) según un morfema al que los gramáticos latinos llaman accidente de persona. Como sujeto de la tercera persona del verbo, ante la carencia de un pronombre personal latino específico para esta función, no dudan éstos en colocar un demostrativo, como podemos comprobar en los siguientes textos de Donato ${ }^{18}$ :

Personae pronominum quot sunt? Tres. Quae? Prima, ut ego, secunda, ut tu, tertia, ut ille.

Personae verborum quot sunt? Tres. Quae? Prima, ut lego, secunda, ut legis, tertia, ut legit.

Este modelo es el que sigue Nebrija tanto en sus Introductiones:

Personae pronominum tres sunt: Prima, ut ego. Secunda ut $i u$. Tertia ut ille. Omnia uero nomina et pronomina sunt tertiae personae: praeter ego quod est primae, et $t u$ quod est secundae, et uocatiui casus oens qui sunt secundae personae. (fol $23 \mathrm{v}$ )

${ }^{18}$ Donati Ars Grammatica, en H. Keil, Grammatici Latini, IV, Hildesheim, New York, Georg Olms Verlag, 1981, págs. 357 y 360. 
Personae uerborum tres sunt: prima, secunda, tertia. Prima quae de se sola uel de se cum aliis loquitur, ut ego amo, nos amamus. Secunda ad quam solam uel cum aliis prima loquitur, ut tu amas, uos amatis. Tertia de qua sola uel de quibus prima loquitur, ut Cicero legit, homines legunt. (fol 19r)

como en la Gramática castellana:

Las personas del pronombre son tres: la primera que habla de si, como io, nos. La segunda a la cual habla la primera, como tú, vos. La tercera de la cual habla la primera, como él, ellos. De la primera persona no ai sino un pronombre: io, nos, mas de las cosas aiuntadas con ella son mio, nuestro, esto, aquesto. De la segunda persona no ai sino otro pronombre: tú, vos \& todos los vocativos de las partes que se declinan por casos, por razón deste pronombre tú que se entiende con ellos, porque tanto vale $o$ Juan lee como tú lee; de las cosas aiuntadas con la segunda persona: tuio, vuestro, esso, aquesso. Todos los otros nombres \& pronombres son de la tercera persona. (págs. 180-181)

Las personas del verbo son tres, como en el pronombre. Primera, como io amo. Segunda, como tú amas. Tercera, como alguno ama. (pág. 186)

Para Nebrija, pertenece a la tercera persona cualquier sustantivo o pronombre excepto yo y tú más los pronombres con ellos relacionados, entre los que incluye los demostrativos este y ese respectivamente. Por eso propone las formas él, ellos como pronombres de tercera persona y, más tarde, alguno como sujeto de la tercera persona del verbo amar. Pero, a pesar de ello, en la tradición gramatical se va imponiendo la consideración de que en el coloquio intervienen tres personas, y de que el pronombre personal de tercera persona es el demostrativo aquel. Así, por ejemplo, Correas justifica la entrada de los demostrativos en el paradigma del pronombre personal de tercera persona de esta manera:

Supónese que una lengua no la hablan más de tres personas, io, tú, aquel. I estas mesmas en plural, nosotros, vosotros, aquellos. (pág. 11).

Se reconocen tres participantes en el acto de habla. Habrá, por lo tanto, tres personas gramaticales. Villalón ${ }^{19}$ ya había propuesto el demostrativo aquel como pronombre personal de tercera persona, porque, en las gramáticas de la época -lo que sigue siendo usual hoy en día-, aquel es el equivalente del demostrativo latino ILLE. Corro ${ }^{20}$ lo incluye junto con se, como hacen

\footnotetext{
19 Licenciado Villalón, Gramática castellana, Madrid, CSIC, 1971, pág. 34.

${ }^{20}$ A. del Corro, Reglas gramaticales para aprender la lengua española y francesa. Madrid, Arco/Libros, 1988, pág. 36.
} 
también Correas y Juan Villar ${ }^{21}$. Ésta era la forma de sujeto que necesitaba el pronombre de tercera persona. En la segunda mitad del siglo XVII, exactamente en 1662, un gramático madrileño afincado en Dinamarca, Carlos Rodríguez ${ }^{22}$, propone por primera vez en una gramática la forma él para la tercera persona singular del pronombre personal. A partir de este gramático, se aceptarán sin discusión las formas yo, tú, él como modelo del pronombre personal. Asi lo hará la primera Gramática de la Academia en 1771, y después, toda la tradición gramatical hasta el día de hoy.

El siguiente paso consiste en completar las casillas vacías del paradigma pronominal de tercera persona por medio de la incorporación de las formas demostrativas que se emplean para referirse a aquellos individuos diferentes de los participantes en el coloquio. El resultado es un paradigma pronomimal de tercera persona formado por elementos de distinta procedencia: los demostrativos él, ella, ello, le, la, lo, y los reflexivos sí, se, consigo. Las formas reforzadas aquel, aquellos, que habían ocupado en las páginas dedicadas a la conjugación verbal de las gramáticas del Siglo de Oro el lugar destinado al sujeto de los verbos de tercera persona, son restituidas a su lugar originario en el paradigma de los demostrativos.

Esta es la situación que suelen presentar las gramáticas del español en la actualidad. Sin embargo, si aceptamos que tan sólo existen dos personas gramaticales - los dos participantes en el coloquio-, hemos de reconocer que tan sólo significan persona gramatical los verbos, los pronombres personales y los posesivos. En ninguna ocasión los demostrativos poseen ese valor morfemático ${ }^{23}$. La persona es un morfema que puede manifestarse por medio de relaciones de concordancia, y esto afecta tan sólo a los verbos, pronombres personales y posesivos, y no a los demostrativos, como puede comprobarse al transformar un enunciado formulado en un tratamiento de familiaridad en otro en el que empleamos un tratamiento de respeto. Así, por ejemplo:

Tú te llevaste este libro a tu casa

se convierte en

Usted se llevó este libro a su casa

\footnotetext{
${ }^{21}$ Propone el siguiente paradigma gramatical del pronombre: yo, tú, se, este, esse, aquel, el mesmo (pág. 16); pero, en las conjugaciones verbales, las formas del pronombre sujeto son: yo, tú, aquel (págs. 31 y ss.). Juan Villar, Arte de la lengua española, Valencia, Francisco Verengel, 1651.

${ }_{22}$ Véase M. L. Viejo Sánchez, Estudios sobre la gramática de Carolus Rodriguez Matritensis (I662), tesis doctoral inédita. Universidad Autónoma de Madrid 1990.

${ }^{23}$ Véase, por ejemplo, F. Marcos Marín, F. J. Satorre Grau y M.* L. Viejo Sánchez, Gramática española, Madrid, Síntesis, 1988, pág. 369.
} 
donde verbos, pronombres personales y posesivos tienen que cambiar su forma en razón de las reglas de la concordancia, mientras que el demostrativo no sufre alteración alguna.

8. Los pronombres él, ella, ello, ellos, ellas, descendientes de demostrativos latinos, cumplen en español papeles semejantes a los que desempeñaban en latín sus étimos ILLE, ILLA, ILLUD. ¿Por qué se les suele considerar como "personales"? Si es porque con ellos podemos designar a la persona que no es ni el hablante ni su interlocutor, igual consideración merecerían éste, ése, aquél, alguien, nadie, alguno, ninguno, otro, cualquiera, el de más allá, fulano, mengano, etc.

En el paso del sistema demostrativo latino al español se observan unas transformaciones que han sido minuciosamente estudiadas por la gramática histórica ${ }^{24}$. Sin embargo, el modelo gramatical del latín ha influido en la interpretación y clasificación de los demostrativos en espanool. El hecho de que el latín tuviera un sistema de tres elementos demostrativos (HIC / ISTE / ILLE), caracterizado por el rasgo distintivo de la indicación de una mayor o menor proximidad con respecto al hablante (por regla general interpretado erróneamente como significación personal: 1. ${ }^{a}$ persona: HIC; $2 .^{a}$ persona: ISTE; $3 .^{a}$ persona: ILLE), formas que podían desempeñar las funciones de núcleo y de adyacente de $\mathrm{SN}$, influye en la creación en español de un esquema semejante: tres elementos con contenidos significativos semejantes y con semejante comportamiento gramatical: este, equivalente al latino HIC; ese, equivalente a ISTE y aquel, equivalente a ILLE. El resto de las formas demostrativas (él, ella, ello, lo, la, $l e$, el, $l a$, y sus respectivos plurales, más el neutro $l o$ ) son acomodadas en otros paradigmas pronominales no demostrativos para no romper la analogía entre los modelos gramaticales latino y español. La separación de estas formas del paradigma de los demostrativos viene coadyuvada por su progresiva pérdida de valor de señalación "ad oculos" que éstas tienen, pero no así de su valor de señalación fórica; además, el comportamiento sintáctico es diferente: él, ella, ello son siempre núcleo de SN, ya sea con función de sujeto o de complemento término de preposición; le, la, lo son

${ }^{24} \mathrm{~S}$. Fernández Ramirez las ha resumido con claridad en su Gramática española. 3.2. El pronombre, Madrid, Arco/Libros, 1987, págs. 95-97. P. Lloyd, Del latín al español. I. Fonologia y morfologia históricas de la lengua española, Madrid, Gredos, 1993, págs. 444-448. M. Alvar y B. Pottier, Morfología histórica del español, Madrid, Gredos, 1987, págs. 102-115 y 119-121. V. Lamiquiz, "El demostrativo en español y en francés", en RFE, L, 1967, págs. 163-202. J. J. Iso, "En torno al sistema deictico pronominal en latín y su paso a las lenguas románicas", en RSEL, 4, 1974, págs. 459-471. F. González Ollé, "Precisiones sobre la etimología de aquel". en Homenaje a Muñoz Cortés, Murcia, 1977, págs. 863-869. 
clíticos, siempre regidos por una forma verbal; mientras que $e l$, la, lo son también formas átonas, pero, por regla general, adyacentes de SN.

En efecto, frente al valor de indicación de proximidad o lejanía de este, ese, aquel, en una situación espacial o temporal determinada, él, ella, ello, $l o, l a, l e$ vienen a significar tan sólo lo que no es ni emisor ni receptor, y $e l, l a, l o$, son reconocedores del sustantivo al que acompañan, todos ellos sin notación de lejanía. Todas estas formas de origen demostrativo han experimentado, pues, un proceso de vaciamiento semántico que las ha conducido a la situación actual, situación en la que necesitan de un contexto o de un entorno determinado para poder adquirir su valor designativo, ya que por ellas mismas tan sólo proporcionan la significación de lo determinado ${ }^{25}$. Por ello, tanto unas formas como las otras se pueden emplear en el seno de un texto para hacer una referencia anafórica, cosa que, como ya se ha observado, no pueden hacer en ninguna ocasión los pronombres personales de primera y segunda personas:

Maria me ha pedido que vaya con ella al cine (ella = María)

María me ha pedido que la acompañe al cine (la = María)

Tengo una bici y voy con ella todos los días al colegio (ella $=$ la bici)

Tengo una bici con la que voy todos los dias al colegio (la = la bici)

De los pantalones que tengo el que más me gusta es el azul (el $=$ el pantalón)

9. Algún gramático, como es el caso de O. Fernández Soriano, justifica la consideración de él, ella, ello, ellos, ellas como pronombres personales aduciendo el argumento de que estos pronombres plenos denotan exclusivamente personas ${ }^{26}$. Pero, observa que pueden tener como referente un objeto no animado en dos circunstancias: cuando son término de preposición, y cuando su uso es obligado. O. Fernández Soriano ${ }^{27}$ ejemplifica este segundo caso con los siguientes enunciados:

Tus observaciones son todas ellas falsas

No es necesario escayolar este hueso. Se soldará \{él solo / él mismo\}

${ }^{25}$ Véase R. Trujillo, Introducción a la semántica española, Madrid, Arco/Libros, 1988, págs. 221-222.

${ }^{26}$ Dice $\mathrm{O}$. Fernández Soriano, "El pronombre personal. Formas y distribuciones. Pronombres átonos y tónicos", en I. Bosque y V. Demonte (dirs.), Gramática descriptiva de la lengua española, 1, 1999, pág. 1220: "Los pronombres de sujeto él/ella. ellos/ellas de la tabla anterior presentan, además, la particularidad de que deben referirse obligatoriamente a personas". $Y$ en nota a pie de página insiste más aún: "En realidad, esta restricción se amplia a todos los casos de pronombre de tercera persona, excepto los que son objeto de preposición".

${ }^{27}$ Id. pág. 1226. En esta página la autora reitera la necesidad de que estos pronombres plenos en español denoten exclusivamente personas. 
Sin embargo, en estos ejemplos el pronombre pleno no es obligatorio; son perfectamente aceptables enunciados como:

Tus observaciones son todas falsas

No es necesario escayolar este hueso. Se soldará solo

Los pronombres plenos él, ella, ello, ellos, ellas, cuando desempeñan la función de sujeto, se emplean preferentemente con referidos personales, pero ello no es de ninguna manera un requisito necesario. Con muchísima frecuencia se refieren a animales, como aparece reflejado en la literatura de todas las épocas, y como se puede comprobar en estos ejemplos extraídos del Quijote, todos ellos perfectamente aceptables en el español actual:

Cuatro días se le pasaron en imaginar qué nombre le pondría; porque, según se decía él a sí mesmo, no era razón que caballo de caballero tan famoso, y $\tan$ bueno él por si, restuviese sin nombre conocido; y ansí, procuraba acomodársele de manera que declarase quién había sido, antes que fuese de caballero andante, y lo que era entonces; pues estaba muy puesto en razón que, mudando su señor estado, mudase él también el nombre. (Quijote, I, 1)

Como Rocinante se vio libre, aunque él de suyo no era nada brioso, parece que se resintió, y comenzó a dar manotadas; porque corvetas - con perdón suyo- no las sabía hacer. $(I, 20)$

Pero, como por aquel lugar inhabitable y escabroso no parecía persona alguna de quien poder informarse, no se curó de más que de pasar adelante, sin llevar otro camino que aquel que Rocinante queria, que era por donde él podía caminar. $(1,23)$

-Recuéstate junto a mí, Manchada, que tiempo nos queda para volver a nuestro apero.

Parece que lo entendió la cabra, porque, en sentándose su dueño, se tendió ella junto a él con mucho sosiego. (I, 50)

Cierto está que este mono no es astrólogo, ni su amo ni él alzan, ni saben alzar, estas figuras que llaman judiciarias, que tanto ahora se usan en España. (II, 25)

Pero también se pueden emplear estos pronombres plenos, en función de sujeto, referidos a realidades no animadas. Véanse, como botón de muestra, estos ejemplos del texto cervantino:

Sólo tiene que aprovecharse de la imitación en lo que fuere escribiendo; que, cuanto ella fuere más perfecta, tanto mejor será lo que se escribiere. (I, Prólogo)

Que la hermosura en la mujer honesta es como el fuego apartado o como la espada aguda, que ni él quema ni ella corta a quien a ellos no se acerca. $(I, 14)$ 
Tentóle luego la camisa, y, aunque ella era de harpillera, a él le pareció ser de finísimo y delgado cendal. ( $I, 16)$

$\mathrm{Y}$ fue rara providencia del sabio que es de mi parte hacer que parezca bacía a todos lo que real y verdaderamente es yelmo de Mambrino, a causa que, siendo él de tanta estima, todo el mundo me perseguirá por quitármele. (I, 25)

No podemos considerar que Cervantes escribía en una lengua diferente de la nuestra, ni que sus usos sean en la actualidad arcaísmos, aunque, tal vez, el hablante actual prefiera en muchos casos emplear otros elementos pronominales en lugar de estos pronombres plenos. Es decir, sería muy probable que el hablante actual dijera:

que la hermosura en la mujer honesta es como el fuego apartado o como la espada aguda, que ni aquél quema ni ésta corta a quien a ellos no se acerca

o

que la hermosura en la mujer honesta es como el fuego apartado o como la espada aguda, que ni el uno quema ni la otra corta a quien a ellos no se acerca

lo que sólo puede interpretarse como una prueba de la equivalencia funcional entre los elementos empleados en estas referencias anafóricas, equivalencia que, por otra parte, puede establecerse siempre, aunque los pronombres en cuestión hagan referencia a entes personales. Es decir, ni él ni ella son pronombres personales; o por lo menos no lo son más que aquél, ésta, el uno o la otra. En la lengua actual es perfectamente normal formular enunciados como el que sigue, en el que el pronombre, referido a un elemento no personal, desempeña la función de sujeto:

A pesar de las dificultades estudié una carrera. Ella me ha dado todo lo que ahora tengo

Especialmente frecuente en la lengua de hoy en día es el empleo de los pronombres él, ella, ellos, ellas en función de sujeto, referidos a cosas, cuando van precedidos del determinante todo:

mas yo, que tengo no sé qué briznas de curioso y de desear saber lo que se me estorba y impide, bonitamente y sin que nadie lo viese, por junto a las narices aparté tanto cuanto el pañizuelo que me tapaba los ojos, y por allí miré hacia la tierra, y parecióme que toda ella no era mayor que un grano de mostaza (Quijote, Il, 41)

Estos usos siguen perfectamente vivos en el español actual. 
Los pronombres no cambian de categoría al mudar de función. No tiene sentido decir que él, ella, ellos, ellas son pronombres personales (denotan exclusivamente personas), salvo cuando son término de preposición o su empleo es necesario. Es absurdo defender que estos pronombres son personales cuando desempeñan la función de sujeto y no lo son cuando son término de preposición. Estos pronombres pueden denotar cualquier referido, personal o no, igual que pueden hacerlo el resto de los demostrativos. En casos como:

Salgo al balcón y estoy en él un rato tomando el sol Aprendi un oficio para vivir de él

Llegaron las lluvias, y con ellas, el fin de la sequia

La princesa llevaba un vestido precioso; todo él estaba cubierto de pedreria fina

no podemos considerar excepcional el empleo del pronombre él por designar realidades no personales. Es su uso normal en todas las épocas de la lengua.

La naturaleza no personal de esos pronombres se manifiesta en un caso como el aducido por la autora antes citada ${ }^{28}$ :

Tus hijos queremos yo trabajar y éste estudiar

En este ejemplo, observamos que los dos participantes en el coloquio aparecen designados por los correspondientes elementos pronominales personales: el posesivo tus señala al receptor y el personal yo al emisor. En cambio, el otro individuo que completa la escena, que no representa ninguno de los papeles de emisor o de receptor, es señalado por el demostrativo éste, claramente no personal, que indica simplemente proximidad al que habla. Es decir, ni todo ser personal diferente de los participantes en el acto de habla tiene que ser designado por los pronombres él, ella, ellos, ellas, ni estos pronombres designan exclusivamente seres personales ${ }^{29}$.

10. Mucho más chocante e inexplicable es el hecho de que se incluya en la lista de los pronombres personales una forma como ello, que nunca

\footnotetext{
${ }^{28}$ O. Fernández Soriano, "El pronombre personal...", en I. Bosque y V. Demonte (dirs.), Gramática descriptiva de la lengua española, op. cit., pág. 1239.

${ }^{29}$ Hace ya más de quince años, R. Trujillo observó que las formas tónicas toman usualmente un valor de persona o, simplemente, de ser animado, en las posiciones de sujeto, objeto directo $e$ indirecto, aunque a veces se den vacilaciones en esta norma [...] pero está claro que se trata de valores contextuales. Véase, R. Trujillo, "La cuestión del artículo en español", en Verba, 14, 1987, pág. 361.
} 
puede hacer referencia a un ente personal. La única razón que explica esta inclusión es la de su forma. Es fácil establecer una relación de analogía formal entre este/esta/esto; eselesa/eso; aquel/aquella/aquello; el/la/lo y él/ella/ello. En todas estas oposiciones el rasgo distintivo es el morfema de género masculino/ femenino/ neutro. Evidentemente, los tres elementos, él, ella y ello forman parte del mismo paradigma por razones de procedencia etimológica y de empleo gramatical en la lengua actual, a pesar del escaso uso que hacen de esta forma neutra los hablantes de hoy en día. Pero, a diferencia de él y ella, que pueden tener como referente un ser personal diferente del hablante y del oyente, ello, debido a su naturaleza gramatical neutra, nunca puede realizar este tipo de referencia. Es lo mismo que sucede en el resto de los demostrativos. Este, esta, ese, esa, aquel, aquella pueden referirse tanto a realidades personales como no personales, mientras que esto, eso, aquello tienen como único referente posible lo no personal. Estamos, por lo tanto, ante una situación común a todos los demostrativos. La relación existente entre ello y él/ella es la misma que existe entre esto y este/esta; eso y ese/esa; aquello y aquel/aquella. El error que ha cometido la gramática no ha sido tanto el de considerar ello como un pronombre personal, sino el de considerar como pronombre personal el paradigma entero él, ella, ello.

11. Los pronombres él, ella, ello, ellos, ellas no son, pues, unas formas que se puedan emplear única y exclusivamente para significar los entes personales diferentes del emisor y del receptor; no son formas específicas para esa función específica. Son vehículo de muchos otros valores, al tiempo que comparten con otras muchas formas pronominales la posibilidad de significar la mal llamada "tercera persona". Él, ella, sus plurales ellos, ellas más el neutro ello constituyen un paradigma de pronombres tónicos fóricos. Siempre tienen función primaria; es decir, siempre funcionan como núcleo de SN. Pero a diferencia de los pronombres personales, tienen un significado opaco, por lo que adquieren su valor designativo por medio de la referencia dentro de un texto, o por medio de signos gestuales o informaciones situacionales complementarias. Pueden hacer referencia a cualquier tipo de sustantivo, sea su significación personal o no. Son unos demostrativos que han perdido su primitivo valor de indicación de lejanía, pero que de ninguna manera se han cargado de significación personal, ya que nunca designan al emisor ni al receptor, y en su uso normal tampoco designan exclusivamente entes personales. Son pronombres que podemos considerar semánticamente "vacíos". Su concordancia se establece en la llamada tercera persona, como cualquier otro pronombre o sustantivo. Como el resto de los demostrativos, 
no varian de forma dependiendo de la función que desempeñen, por lo que la mantienen tanto cuando cumplen el papel de sujeto como cuando son complemento término de preposición.

Estos pronombres, no marcados desde el punto de vista de la deixis, pueden desempeñar cualquier función propia de su naturaleza de núcleo de SN. Sin embargo hemos de observar alguna restricción funcional. No pueden usarse como complemento verbal sin ir introducidos por una preposición $^{30}$, a no ser que vayan precedidos por el cuantificador todo.

Recogió del suelo libros y cuadernos y dejó todo ello sobre la mesa

*Recogió del suelo libros y cuadernos y dejó ello sobre la mesa

Se le ha caido en la cocina un litro de aceite y la ha dejado toda ella manchada

* Se le ha caido en la cocina un litro de aceite y la ha dejado ella manchada

El bibliotecario recogia del depósito los libros y colocaba todos ellos en los estantes

*El bibliotecario recogía del depósito los libros y colocaba ellos en los estantes

12. Algo semejante ocurre con los pronombres átonos $l o / l a / l e$ y sus respectivos plurales. Nunca tienen como referido ni al emisor ni al receptor, y su posibilidad de designar entes personales es equiparable a la de designar entes no personales:

He visto a Juan pero no lo he saludado

He comprado un libro pero no lo he leido

He visto a Maria pero no la he saludado

He comprado una novela pero no la he leido

He visto a Irene y le he dado un disco

He comprado un libro $y$ le he puesto un forro

No hay ninguna razón para defender la naturaleza personal de estos pronombres. Son simplemente pronombres que realizan una referencia

\footnotetext{
${ }^{30}$ R. Trujjllo, "La cuestión del artículo", art. cit., pág. 361: "Los pronombres sujeto de primera y segunda persona son necesariamente personales y de ahi su extensión analógica a la tercera; las formas tónicas precedidas de la preposición $a$, acusativos o dativos, son igualmente personales por regla general, como es bien sabido. Si además se tiene en cuenta que tanto unos como otros son redundantes y enfáticos, la cosa parece explicarse harto fácilmente, pese a que no son imposibles los referentes de cosa [...] Los vaiores personales, pues, que concurren en los usos enfáticos y pleonásticos de sujeto y de térrninos de la preposición a no son otros que los que resultan usuales en tales posiciones y nada tienen que ver con el contenido invariable de estas unidades".
} 
dentro de un texto o en una situación dada. Estos pronombres clíticos, como también los pronombres tónicos él, ella, ello, ellos y ellas, han experimentado un proceso de vaciado semántico; tan sólo conservan su significación de determinación. Es preciso que el oyente conozca previamente el valor designativo de estos pronombres, o por medio de los elementos textuales ya emitidos, o a través de señalaciones situacionales o alusiones al conocimiento compartido por los interlocutores. Por eso son inaceptables enunciados como:

*La madre lo besó y acarició a su hijo

Es necesario el orden inverso para que el clítico $l o$ pueda realizar su referencia anafórica al sustantivo hijo:

\section{La madre besó a su hijo y lo acarició}

El carácter determinado de estos pronombres se manifiesta en la necesidad de hacer referencia a un antecedente determinado. Sólo pueden emplearse para referirse a elementos determinados o previamente presentados. Por eso observa Trujillo ${ }^{31}$ la correspondencia entre los siguientes enunciados:

Tiene el dinero / Lo tiene

Tiene dinero / Tiene

Un enunciado como:

Compró un libro y lo leyó

es posible porque libro, que ha sido previamente presentado, ya es un elemento determinado.

No existe ningún tipo de analogía, ni formal ni semántica, entre estos clíticos y los pronombres personales átonos me y te. Los pronombres personales átonos significan persona gramatical; tienen una significación transparente, por lo que en ninguna ocasión su valor designativo se puede proporcionar a través de una referencia anafórica.

Tampoco hay semejanza en lo relativo a la forma. Los pronombres clíticos lo/los, la/las, le/les, debido a su origen etimológico, presentan marcas flexivas regulares de número y diferente forma según la función sintáctica que desempeñen; además, las formas procedentes de los acusativos latinos tienen marcas flexivas de género: $l o, \mathrm{CD}, \mathrm{m}$. sg.; los, $\mathrm{CD}, \mathrm{m}$. pl; $l a, \mathrm{CD}, \mathrm{f}$. sg.; las, CD, f. pl.; le, CI, sg.; y les, $\mathrm{CI}$, pl., cosa que de ninguna manera ocurre en el caso de los pronombres personales.

${ }^{31}$ R. Trujillo, Introducción a la semántica española, op. cit. pág. 222. 
Estos pronombres son simplemente pronombres anafóricos. No hay ningún argumento que nos obligue a considerarlos como personales. Establecen una referencia anafórica a cualquier elemento sustantivo, pronominal e, incluso, oracional, excepto a los que significan primera o segunda personas:

Compró una novela y la leyó de un tirón $(l a=$ novela)

Toma esto y ponlo alli (lo $=$ esto)

— ¿Sabes que Maria se ha casado? -Lo sé (lo = que Maria se ha casado)

Los pronombres personales átonos pueden emplearse, en las construcciones pleonásticas, tan sólo junto a otro pronombre personal tónico de su misma persona ${ }^{32}$ :

A mi me gusta el café

A ti te vieron en el cine

${ }^{*} A$ mi te gusta el café.

${ }^{*}$ A Daniel te vieron en el cine

Estos pronombres clíticos no personales, en cambio, pueden aparecer referidos a otros pronombres; no necesariamente a él, ella, ello, ellos, ellas, y a cualquier sustantivo:
$A$ él lo vieron en el cine
$A$ ese lo vieron en el cine
$A$ ella la vieron en el cine
$A$ esa la vieron en el cine
$A$ él le gusta el café
A ese le gusta el café
El café no le gusta a ese; le gusta a otro
El café le gusta a cualquiera
Le he comprado un libro a Marisa
Le voy a poner un forro a este libro
Este libro lo lei de un tirón
La carpeta la dejé sobre la mesa

Esto no invalida lo dicho arriba: estos pronombres equivalen, desde el punto de vista semántico a construcciones con complemento determinado por el artículo:

He leído la novela / La he leido

He leído una novela / He leido una

${ }^{32}$ Vid. F. Marcos Marín, Estudios sobre el pronombre, Madrid, Gredos, 1978, págs. 71-122. 
He leido esta novela / He leido ésta

He leido novelas / He leido

13. El conocimiento de otras lenguas, pero, sobre todo, la observación del modelo gramatical griego lleva a Nebrija a postular en castellano una categoría gramatical desconocida en la lengua latina a la que denomina "artículo":

Todas las lenguas, cuantas he oido, tienen una parte de la oración, la cual no siente ni conoce la lengua latina. Los griegos llaman la arteon; los que la bolvieron de griego en latín llamaron le artículo, que en nuestra lengua quiere dezir artejo; el cual en el castellano no significa lo que algunos piensan, que es una coiuntura o ñudo de los dedos; antes se an de llamar artejos aquellos uessos de que se componen los dedos. Los cuales son unos pequeños miembros a semejança de los cuales se llamaron aquellos artículos que añadimos al nombre para demostrar de qué género es. $\mathrm{E}$ son los artículos tres: $e l$, para el género masculino; $l a$, para el género feminino; lo, para el género neutro. '(pág. 182)

Pero estos artículos el, la, lo, los, las, a los que la gramática denominará más tarde "determinados", tienen su origen en los demostrativos latinos ILLE, ILLA, ILLUD ${ }^{33}$. El origen pronominal de los artículos y su consecuente parentesco con los demostrativos ( $\mathrm{y}$ con los pronombres comúnmente considerados personales de tercera persona, derivados de éstos) ha motivado un debate acerca de si el artículo es un tipo de pronombre ${ }^{34}$, es un tipo de palabra diferente, por lo general incluida en una clase de determinantes o actualizadores ${ }^{35}$, o es, simplemente, un morfema del sustantivo ${ }^{36}$. Recientemente, Á. López ${ }^{37}$, desde un punto de vista perceptivo, ha interpretado el artículo, junto con el resto de los pronombres, como internombres, es decir, como fronteras entre la figura sustantivo y el fondo adjetivo, lo que explica, según este lingüista, que puedan manifestarse a la manera de los sustantivos o a la manera de los adjetivos.

El artículo es un adjetivo demostrativo que ha perdido su notación de lejanía ${ }^{38}$, pero su naturaleza sigue siendo de la misma índole que la de la

${ }^{33}$ Rafael Lapesa, "Nominativo o caso oblicuo latinos como origen de demostrativos y artículo castellanos", en Estudios de morfosintaxis histórica del español, Madrid, Gredos, 2000, págs. 346-359; "Del demostrativo al artículo", en Estudios de morfosintaxis..., op. cit., págs. $360-387$.

${ }_{34}$ A. Bello, Gramática de la lengua castellana (1847), Madrid, Edaf, 1978, \$273.

35 R. Lapesa, "Un, una, como articulo indefinido en español", en Estudios de morfosintaxis..., op. cit., págs. $480-482$.

${ }^{36}$ E. Alarcos Llorach, Estudios de gramática funcional..., op. cit., pág. 146.

37 A. López, Gramática del español. III Las partes de la oración, Madrid, Arco/Libros, 1998 , págs. 252-253.

${ }^{38}$ R. Lapesa, "Del demostrativo al artículo", en Estudios de morfosintaxis..., op. cit.. págs. $367-368$. 
categoría de la que procede; por eso, ambos pueden usarse para hacer referencia anafórica a una entidad o conjunto de entidades ${ }^{39}$. Claro está que ha formado una nueva clase de palabras que tiene diferente significación, unas formas distintas y unos empleos exclusivos suyos, que lo diferencian de los demostrativos (como es el caso de los usos generalizadores o el hecho de que nunca tenga autonomía sintáctica), pero no debe extrañarnos que conserve comportamientos semejantes. Con frecuencia se ha constatado la equivalencia designativa de construcciones con las formas mencionadas. Así, por ejemplo, en un párrafo de este mismo texto escrito más arriba, se decía:

El siguiente paso consiste en completar las casillas vacías del paradigma pronominal de tercera persona por medio de la incorporación de las formas demostrativas que se emplean para referirse a aquellos individuos diferentes de los participantes en el coloquio.

Igual hubiéramos podido escribir:

El siguiente paso consiste en completar las casillas vacias del paradigma pronominal de tercera persona por medio de la incorporación de aquellas formas demostrativas que se emplean para referirse a los individuos diferentes de los participantes en el coloquio.

Además, es llamativo el hecho de que el español emplee artículos en contextos en los que otras lenguas románicas, como el francés o el italiano, usan demostrativos ${ }^{40}$ :

El alto / Celui qui est haut

Llevaba la melena revuelta como la de un león / Elle avait sa crinière ébouriffée comme celle d'un lion

No sabes lo que dices / Tu ne sais pas ce que tu dis ${ }^{41}$

El parentesco evidente que existe entre los artículos $e l, l a, l o$ y los pronombres él, ella, ello ha sido frecuentemente destacado por muchos gramáticos, como es el caso de Bello, quien llega a identificar ambas formas. Para él, sólo hay una palabra que adopta formas distintas según sea adjetivo o sustantivo:

\footnotetext{
${ }^{39}$ J. C. Moreno Cabrera, Curso universitario de lingüistica general. I, Madrid, Sintesis, 1991, pág. 280

${ }^{40}$ R. Lapesa, "El, la, lo como antecedente de relativo en español", en Estudios de morfosintaxis..., op. cit. pág. 389.

${ }^{41}$ Ejemplos tomados de Jean-Marc Bedel, Grammaire de l'espagnol moderne, París, Presses Universitaires de France, 1997, págs. 78-79.
} 
Los demostrativos este, ese, aquel, se sustantivan como los otros adjetivos, y eso mismo sucede con el artículo, que toma entonces las formas él (con acento), ella, ellos, ellas, [...]: "El criado que me recomendaste no se porta bien; no tengo confianza en él": él es el criado que me recomendaste; "La casa es cómoda; pago seiscientos pesos de alquiler por ella": ella es la casa; "Los árboles están floridos; uno de ellos ha sido derribado por el viento": ellos reproduce los árboles; "Las señoras acaban de llegar; viene un caballero con ellas": ellas se refiere a señonas. Hemos visto [...] que la estructura material de varios nombres se abrevia en situaciones particulares: parece, pues, natural que miremos las formas el, la, los, las como abreviaciones de él, ella, ellos, ellas, y éstas últimas como las formas primitivas del artículo. (A. Bello, Gramática de la lengua castellana, § 273)

Esta relación proporcional que establece Bello entre las formas sustantiva y adjetiva de los demostrativos por una parte, y los pronombres él, ella, ello, ellos, ellas y los artículos determinados por otra, lo que viene a demostrar es que estos pronombres no tienen más valor personal que el artículo. El artículo, al igual que los demostrativos y los pronombres él, ella, ello, ellos, ellas, no tiene significación personal alguna, de forma que, cuando realiza referencias anafóricas, to hace como los demostrativos, clase de la que históricamente procede, y no como un pronombre personal. Asi, en el siguiente ejemplo, extraído de un texto de Julián Marías $(A B C, 21-\mathrm{I}-99)$ :

El hombre, a lo largo de su vida, es el mismo, pero no es lo mismo

está clara la referencia anafórica del artículo el a su antecedente hombre; lo que no ocurre con el neutro $l o$. El sentido del texto es:

El hombre, a lo largo de su vida, es el mismo hombre, pero no la misma cosa

Si no se tiene en cuenta el valor anafórico del artículo, no pueden entenderse textos como éste. Esta referencia es independiente de la persona gramatical del antecedente. Se puede decir perfectamente:

Yo, a lo largo de mi vida, soy el mismo, pero no lo mismo

Tú, a lo largo de tu vida, eres el mismo, pero no lo mismo

El artículo debe reflejar fielmente el género y el número de su antecedente, pero no la persona:

Ella, a lo largo de su vida, es la misma, pero no lo mismo

Nosotros, a lo largo de nuestras vidas, somos los mismos, pero no lo

mismo 
Ambas series de formas, el, la, lo, los, las y él, ella, ello, ellos, ellas tienen el mismo origen etimológico, y ambas han perdido su valor de señalación de lejanía, es decir, han experimentado un proceso de gramaticalización semejante. Se diferencian claramente por la forma átona de la primera serie frente al carácter tónico de la segunda y, sobre todo, por la función. Los artículos son elementos que no tienen autonomía sintáctica, es decir, que nunca pueden aparecer solos, mientras que la segunda serie está constituida por elementos con función exclusivamente de núcleo de $\mathrm{SN}$. Frente a estas formas, los pronombres clíticos le, la, lo, les, las, los, originariamente también demostrativos que, como las series anteriores, se han vaciado semánticamente, perdiendo su notación de lejanía, son fonmas regidas por un verbo al que complementan, desempeñando las funciones de CI y de CD. Pero la relación entre estas tres series, que tienen el mismo origen etimológico y que han sufrido el mismo proceso de pérdida de valor léxico, se mantiene en la lengua actual. Son elementos léxicamente vacíos, básicamente referenciales, que exigen, para poder utilizarse, un referido conocido por el emisor y por el receptor ${ }^{42}$. En ningún momento pueden integrarse en una categoría de pronombres personales, porque no hacen más referencia a seres personales que otros pronombres como los demostrativos o como los indefinidos alguno, ninguno, mucho, poco, cualquiera, otro, etc.

No me parece desacertada la opinión de R. Trujillo ${ }^{43}$, quien postula que estas tres series derivadas del demostrativo latino ILLE no son más que variantes combinatorias de un mismo signo, caracterizado por la función semántica "determinante".

14. En la lengua latina, a los pronombres personales ( $\mathrm{EGO}, \mathrm{TU}$ ), correspondía una serie de elementos adjetivos (MEUS, TUUS), a los que la gramática ha denominado tradicionalmente como posesivos ${ }^{44}$. SUUS, que en un principio era una forma esencialmente reflexiva que entraba en serie con SUI, SIBI, SE, deja de hacer referencia exclusivamente al sujeto y pasa a comportarse como un posesivo ${ }^{45}$. Hemos de aceptar esta denominación de

\footnotetext{
${ }^{42}$ Dice M. Leonetti Jungl, El artículo y la referencia, Madrid, Taurus, 1990, pág. 44: "Si el habiante se refiere a algo por medio de el, este o ese, indica al oyente que el referente existe y es localizable. Al usar un indefinido, en cambio, el hablante indica que la existencia y la identidad del referente no forman parte de la experiencia común, compartida con el oyente". De manera semejante, J. C. Moreno Cabrera, Curso universitario de lingüistica general, op. cit., I, pág. 278, considera que el artículo "se convierte en marcador obligatorio de definidad".

${ }^{43}$ R. Trujillo, Introducción a la semántica española, op. cit., págs. 144; 172; 221-222.

${ }_{44}$ M. Bassols de Climent, Sintaxis Latina, 1, op. cit. pág. 191.

${ }^{45}$ M. Bassols de Climent, Sintaxis Latina, 1, op. cit. pág. 194. O Riemann, Syntaxe latine, Paris, Klincksieck, 1942, págs. 29-30. M. Leumann, J. B. Hofmann y A. Szantyr, Lateinische Grammatik, II, München, C. H. Beck, 1977, págs. 174-175.
} 
posesivo como una etiqueta que nombra a una clase, y no como un término semánticamente transparente, ya que el posesivo no indica posesión más que de manera circunstancial, como lo pueden hacer los pronombres personales. Varios son los estudiosos que han observado que la función del posesivo no es la expresión de la posesión, sino la señalación de las personas gramaticales ${ }^{46}$. Teniendo en cuenta esta íntima relación existente entre los personales y los posesivos, S. Fernández Ramírez considera los posesivos españoles como personales adjetivos ${ }^{47}$. Según R. Lenz la principal diferencia entre personales y posesivos reside en que:

los personales reemplazan a los sustantivos relacionados con el acto de la palabra en sus relaciones más o menos pasajeras con el verbo (el fenómeno), mientras los posesivos indican las relaciones más o menos duraderas que existen entre los sustantivos (personas, cosas o cualidades) y las personas que participan en el acto de la palabra. Aquéllos son elementos primarios (sujetos y complementos de cualquier especie) de la oración; éstos son atributos de sustantivos $y$, de consiguiente, elementos secundarios ${ }^{48}$.

Así pues, los posesivos, según el lingüista chileno, se caracterizan por su función adjetiva y por su carácter relacional. De esta misma opinión es Porto, cuando dice que "la función de los pronombres posesivos es indicar una relación entre el objeto representado por el sustantivo a que se refieren y una persona gramatical" ${ }^{49}$. De ello deduce que los posesivos tienen dos contenidos diferentes: un contenido relacional, común a otros adjetivos, y un contenido personal, que los diferencia de ellos. El contenido relacional puede variar dependiendo del sentido que adquiera el posesivo en el contexto en el que se halle; el contenido personal es invariable. Así, por ejemplo, en un sintagma como mi fotografia, el posesivo, según el contexto, puede indicar, por una parte o que yo salgo retratado en la fotografia, o que yo he hecho la fotografia, o que dicha fotografía es de mi propiedad (contenido relacional); pero en todas las ocasiones está refiriéndose a la primera persona, al emisor del mensaje (contenido personal).

La significación personal es evidente en los posesivos mi, mis, mio, mia, mios mias / tu, tus, tuyo, tuya, tuyos, tuyas. En las formas de varios poseedores, nuestro, nuestra, nuestros, nuestras / vuestro, vuestra,

46 A. Costa Olid, El posesivo en español, Sevilla, Universidad de Sevilla, 198I, pág. 23. José Á. Porto Dapena, "Los posesivos personajes del español: intento de descripción funcional", en Dicenda, I, 1982, pág. 102; Los pronombres, Madrid, Edi-6, 1986, págs, 115-116.

47 S. Femández Ramirez, Gramática española. 3.2. El pronombre, Madrid, Arco/Libros, 1987, págs. 83-84.

${ }_{48}^{8}$ R. Lenz, La oración y sus partes, Madrid, Centro de Estudios Históricos, $2 .^{a}$ ed., 1925, \& 163, pág. 253.

49 Á. Porto, Los pronombres, op. cit., pág. 116. 
vuestros, vuestras, la significación personal aparece en tanto en cuanto hacen referencia a un conjunto de elementos entre los que se encuentra el emisor y el receptor, respectivamente. Los posesivos su, sus, suyo, suya, suyos, suyas, en cambio, hacen referencia a lo que no es emisor ni receptor; no sólo a los pronombres él, ella, ello, ellos, ellas, como frecuentemente se suele decir, sino a cualquier sustantivo o pronombre, excepción hecha de yo y tú.

Los posesivos son adjetivos personales ${ }^{50}$, caracterizados, como los pronombres personales y los verbos, por tener morfema de persona. Están emparentados con los pronombres personales desde el punto de vista genético y semántico ${ }^{51}$, aunque ello no es motivo suficiente para incluirlos en la misma clase que los pronombres personales, ya que constituyen un sistema autónomo ${ }^{52}$.

Los pronombres personales son sustantivos personales. Los posesivos, adjetivos personales. Los pronombres personales designan a los participantes en el coloquio; los posesivos establecen una relación entre un objeto poseido y el poseedor, que puede ser una de las personas gramaticales $-m i$, mio / tu, tuyo-, o lo que no es ni emisor ni receptor $-s u$, suyo-. Existe una relación semajante entre:

\section{Cervantes / Una obra cervantina}

$\mathrm{y}$

Tú / Una obra tuya

Los pronombres personales tienen su propio género y número, derivado de la realidad personal del hablante o del interlocutor; de manera que yo concuerda en singular masculino si el que habla es varón (yo soy profesor), y en singular femenino si es mujer (yo soy profesora), y lo mismo podemos decir de tú (tú eres profesor / tú eres profesora). En los posesivos, en cambio, el género y el número de éstos les viene impuesto por el SN del que dependen, llamado comúnmente en gramática el objeto poseido, mientras que el poseedor les impone tan sólo el morfema de persona. Son, por lo tanto, palabras que funcionan de manera diferente, tanto desde el punto de

\footnotetext{
${ }^{50}$ La discusión sobre la naturaleza categorial de los posesivos ya la he recogido en otro lugar. Ver F. J. Satorre Grau, Los posesivos en español Valencia, Universitat de València, 1999, págs. 18-25.

51 Es llamativo que el español no haya admitido la entrada de los demostrativos en los paradigmas de los posesivos, a diferencia de to que han hecho otras lenguas europeas. En la lengua española, todos los posesivos son formas derivadas de los pronombres personales correspondientes, o de los pronombres reflexivos.

${ }_{2}$ De esta opinión es Á. López Garcia, Gramática del español. III. Las partes de la oración, Madrid, Arco/Libros, 1998, pág. 271.
} 
vista morfosintáctico como semántico; pertenecen a categorias gramaticales distintas ${ }^{53}$. Los pronombres personales, desde el punto de vista sintáctico, desempeñan siempre una función primaria, es decir, son sustantivos funcionales, mientras que los posesivos siempre desempeñan una función secundaria, dicho de otro modo, son adyacentes de un SN.

Sin embargo, aunque personales y posesivos constituyen clases gramaticales diferentes, el parentesco existente entre ambos tipos de palabras permite que en español, con mucha frecuencia, podamos expresar tanto contenidos posesivos por medio de pronombres personales, como contenidos personales por medio de posesivos. En un enunciado como:

Voy en tu auxilio

el posesivo $t u$ no aporta ninguna significación posesiva - no se está diciendo que "el auxilio te pertenece"-, sino un valor estrictamente personal (voy en auxilio de ti, voy a auxiliarte). De manera semejante, en:

\section{Te lavas la blusa}

el pronombre personal te es portador de valores posesivos. El enunciado tiene un valor equivalente a lavas tu blusa. Esta conducta es especialmente frecuente en aquellos casos en los que se expresa posesión inalienable, casos en los que el español manifiesta una clara preferencia por la expresión de la posesión por medio de pronombres perșonales (los llamados dativos posesivos), en lugar de emplear posesivos ${ }^{54}$.

Los posesivos en español, a diferencia de otras lenguas románicas, se organizan en dos series, una átona y otra tónica. La serie átona aparece necesariamente antepuesta al sustantivo del que depende entonativa y acentualmente, presenta formas apocopadas $(m i, t u, s u / m i s$, $t u s$, sus) salvo en las correspondientes a las primera y segunda personas de varios poseedores (nuestro, vuestro / nuestros, vuestros), y se caracteriza por su naturaleza determinante, lo que la hace incompatible con el artículo. La serie tónica, constituida por formas plenas, no tiene esta restricción, ya que puede suceder al sustantivo (este hijo mio) o acompañar al artículo (el mio) o a otros determinantes (este mío, otro mio, alguno mio). No tiene valor determinante, por lo que exige que el sustantivo del que es adyacente vaya actualizado por otro elemento gramatical (este hijo mio, otro hijo mio, un hijo mio).

\footnotetext{
${ }^{53}$ No son los genitivos de los pronombres personales. Ver E. Alarcos, Gramática estructural, Madrid, Gredos, 1977, págs. 92-93.

${ }_{54}$ F. J. Satorre Grau, "Formas de expresión de la posesión en el español medieval", en $A c$ tas del $\mathrm{IV}$ Congreso Internacional de Historia de la Lengua Española, vol. 1, Logroño, Universidad de La Rioja, 1998, págs. 793-804.
} 
15. Como ya se ha observado más arriba, algunos de nuestros primeros gramáticos - Nebrija, el anónimo autor de la gramática de Lovaina de 1555, Miranda, Oudin y Franciosini-clasificaron conmigo, contigo y consigo entre los adverbios, constituyendo una categoria de "adverbios personales". No argumentan su manera de proceder, pero, sin duda, debe influir en ella la constatación de que se trata de palabras invariables. De hecho, la intuición idiomática del hablante normal no es suficiente para interpretar el origen etimológico de estas palabras. Obsérvense las reservas que manifiesta el maestro Correas cuando, en su Arte de la lengua española castellana, habla de estas formas:

Los tres ablativos, conmigo, contigo, consigo, con la preposizión con rreziben siempre al fin esta silaba go, i no se usan de otra manera: pudo ser que naziesen de los Latinos mecum, tecum, secum, antepuesta la preposizión Castellana con (pág. 161).

A partir del momento en el que los gramáticos han visto con claridad que el origen de estas formas hay que buscarlo en la reduplicación de la preposición CUM con el pronombre personal ablativo latino, CUMMECUM, CUMTECUM, CUMSECUM, han incluido conmigo, contigo y consigo en el grupo de los pronombres personales, como una forma específica para su empleo como pronombre complemento tónico, término de la preposición con.

Pero, ¿qué argumentos se han esgrimido para sacar estas palabras del grupo de los adverbios e incluirlas en el de los pronombres? En ningún lugar hemos encontrado este razonamiento. Todo nos lleva a pensar que el argumento principal consiste en su origen etimológico. Sin embargo, después de un examen objetivo del comportamiento gramatical de estas formas, observamos que se trata de palabras invariables, caracterizadas exclusivamente por tener morfema de persona, ligado a su marca léxica, sin ningún tipo de flexión. Su empleo gramatical corresponde al de los complementos introducidos por la preposición con. Fundamentalmente se trata de complementos circunstanciales de compañia (Daniel viene conmigo al cine), pero también pueden desempeñar la función de suplemento (Para este proyecto, cuenta conmigo). Todo lo dicho hasta aqui es característico de los adverbios ${ }^{55}$.

$\mathrm{Si}$ se arguye que estos elementos no son adverbios porque son permutables por pronombres personales tónicos, o por otros pronombres, intro-

\footnotetext{
${ }^{35}$ Recuérdese la definición que E. Alarcos da de adverbio: "En sentido estricto, adverbio designa una clase de palabras invariables en su significante y a menudo indescomponibles en signos menores, destinadas en principio a cumplir por si solas el papel de adyacente circunstancial del verbo". E. Alarcos Llorach, Gramática de la lengua española, Madrid, EspasaCalpe, 1994, pág. 128.
} 
ducidos por la preposición con (viene conmigo / viene con nosotros / viene con él / viene con otro...; cuenta conmigo / cuenta con vosotros / cuenta con ella / cuenta con otro...), y que, por lo tanto, pertenecen a la misma categoría pronominal que éstos, se puede contestar que no es un caso único. La lengua española tiene adverbios que, en su origen, son elementos sustantivos introducidos por una preposición (encima, enfrente, deprisa, despacio, etc.) Estos adverbios pueden usarse también en contextos donde aparecen sintagmas nominales introducidos por la misma preposición:

Dejó los libros encima de la mesa

Dejó los libros en un cajón de la mesa

y no por eso dejan de ser adverbios. Es más, con mucha frecuencia se puede observar que un adverbio puede permutarse por un SN introducido por preposición o por un pronombre tónico prẹcedido por la misma preposición:

Entró alli

Entró en el despacho

Entró en él

Conmigo, contigo, consigo pueden ser considerados como adverbios tanto cuando desempeñan funciones de complemento circunstancial, como cuando desempeñan funciones de suplemento, porque en ambas funciones el SN puede ser conmutable por un adverbio ${ }^{56}$.

No hay ningún argumento convincente para que conmigo, contigo y consigo no deban ser considerados como adverbios. Tienen una forma invariable, porque no admiten ningún tipo de flexión, de derivación ni de composición, y desempeñan exclusivamente funciones propias de su naturaleza adverbial sin requerir, para ello, el auxilio de ninguna preposición (al igual que encima, enfrente, deprisa, despacio, etc.).

De estos adverbios, conmigo y contigo son personales, ya que hacen referencia al emisor y al receptor, mientras que consigo es simplemente un adverbio reflexivo, como reflexivos son los pronombres si, se con los que genéticamente está emparentado.

16. El morfema de persona en la lengua española es privativo de determinados tipos de palabras que se pueden caracterizar por medio de procedimientos formales, funcionales y semánticos. En el verbo, palabra que tie-

36 E. Alarcos Llorach, La noción de suplemento, Logroño, Gobierno de La Rioja, 1990, págs. 12-15. Los "suplementos inherentes" o "adverbiales" son complementos argumentales del verbo, introducidos por preposición, no integrables por pronombres átonos y sí por un adverbio. 
ne un valor designativo ligado a su base léxica, la persona se manifiesta a través de marcas flexivas (am-o, am-as, am-a). En el resto de las palabras que en español tiene morfema de persona, éste aparece ligado a la marca léxica, de modo que, sólo cambiando el lexema se puede cambiar la persona (yo / tú; mio / tuyo; conmigo / contigo). Si una clase de palabras puede identificarse por su capacidad de combinarse con determinado morfema (de hecho el verbo puede definirse como aquella clase de palabras en las que un lexema se combina con morfemas de tiempo, modo, aspecto, número y persona), podemos postular una superclase de elementos, a los que podemos llamar personales, caracterizados por tener el morfema de persona y no los de tiempo, modo y aspecto. Esta superclase de palabras estaría formada por tres categorías de palabras diferenciadas por su función sintáctica: los sustantivos personales $(y o, m i, m e / t u, t i, t e)$, que sólo pueden desempeñar la función de núcleo de $\mathrm{SN}$; los adjetivos personales (mio, mi / tuyo, tu), que siempre tienen una función adjetiva, y por los adverbios personales (conmigo, contigo), que presentan una forma invariable y desempeñan simpre funciones adverbiales.

17. Según esto, propongo una ordenación de los elementos pronominales heredados del latín, y que Nebrija agrupa conjuntamente en su Gramática castellana, según hemos visto, en la que se separen claramente los elementos personales de los no personales. El paradigma de palabras personales, está constituido por las siguientes formas:

\begin{tabular}{|l|l|l|l|}
\hline \multirow{4}{*}{ Sustantivos } & Primera persona & Segunda persona \\
\cline { 2 - 4 } & Sujeto & $Y o$ & $T i$ \\
\cline { 2 - 4 } & $\begin{array}{l}\text { Complementos tónicos, } \\
\text { términos de preposición }\end{array}$ & $M i$ & $T \mathrm{~T}$ \\
\cline { 2 - 4 } & Complementos cliticos & Me & $T e$ \\
\hline Adjetivos & Tónicos & Mio, -a, -OS, -as & Tuyo, -a, -os, -as \\
\cline { 2 - 4 } & Átonos & Mi, mis & Tu, tus \\
\hline Adverbios & & Conmigo & Contigo \\
\hline
\end{tabular}

\begin{tabular}{|l|l|l|l|}
\hline \multirow{3}{*}{ Sustantivos } & $\begin{array}{l}\text { Sujeto y complementos } \\
\text { tónicos, términos } \\
\text { de preposición }\end{array}$ & Nosotros, -as & Vosotros, -as \\
\cline { 2 - 4 } & Complementos clíticos & Nos & Os \\
\hline Adjetivos & Tónicos & Nuestro & Vuestro \\
\cline { 2 - 4 } & Átonos & Nuestro & Vuestro \\
\hline
\end{tabular}


Los pronombres reflexivos constituyen una categoría aparte. Su formas —idénticas para el singular y para el plural-- son:

\begin{tabular}{|l|l|l|}
\hline \multirow{2}{*}{ Uustantivos } & Complemento clítico & Se \\
\cline { 2 - 3 } & Complemento tónico, término de preposición & Si \\
\hline Adverbio & & Consigo \\
\hline
\end{tabular}

\section{Posesivos no personales:}

\begin{tabular}{|l|l|l|}
\hline \multirow{2}{*}{ Adjetivos } & Tónicos & Suyo, suya, suyos, suyas \\
\cline { 2 - 3 } & Átonos & Su, sus \\
\hline
\end{tabular}

Los demostrativos tienen unos paradigmas coincidentes con los propuestos habitualmente por la tradición gramatical:

\begin{tabular}{|l|l|l|}
\hline Sustantivos & Proximidad al emisor & Este, esta, esto, estos, estas \\
\cline { 2 - 3 } & Distancia media con respecto al emisor & Ese, esa, eso, esos, esas \\
\cline { 2 - 3 } & Lejania del emisor & $\begin{array}{l}\text { Aquel, aquella, aquello, aquellos, } \\
\text { aquellas }\end{array}$ \\
\hline
\end{tabular}

\begin{tabular}{|l|l|l|}
\hline Adjetivos & Proximidad al emisor & Este, esta, estos, estas \\
\cline { 2 - 3 } & Distancia media con respecto al emisor & Ese, esa, esos, esas \\
\cline { 2 - 3 } & Lejanja del emisor & Aquel, aquella, aquellos, aquellas \\
\hline
\end{tabular}

Es necesario proponer un nuevo paradigma de elementos no personales, de origen demostrativo, que han experimentado un proceso de vaciado semántico, perdiendo completamente su indicación de lejanía con respecto al emisor. A falta de mejor manera de denominarlos, podemos emplear el término de "elementos referenciales determinados":

\begin{tabular}{|l|l|l|l|}
\hline \multirow{3}{*}{ Sustantivos } & \multicolumn{2}{|l|}{$\begin{array}{l}\text { Sujeto y complementos tónicos, términos de } \\
\text { preposición }\end{array}$} & El, ella, ello, ellos, ellas \\
\cline { 3 - 4 } & \multirow{2}{*}{ Complementos cliticos } & CD masc. & Lo, los \\
\cline { 3 - 4 } & & CD fem. & $L a, l a s$ \\
\cline { 3 - 4 } & & CI & $L e_{,} l e s$ \\
\hline Adjetivos & ("Artículo determinado") & El, la, lo, los, las \\
\hline
\end{tabular}


18. CONCLUSIÓN

Las palabras que significan persona en español sólo son las de primera y segunda personas, es decir, las que señalan directamente al emisor o al receptor, participantes en el acto de comunicación. Por lo tanto sólo los pronombres yo, mi, me, tú, ti, te, nosotros, nosotras, nos, vosotros, vosotras, os, a los que podemos llamar perfectamente "sustantivos personales", los posesivos mio, mi, tuyo, tu, nuestro, vuestro más sus respectivos plurales, a los que podemos denominar "adjetivos personales", y los adverbios personales conmigo y contigo tienen derecho a pertenecer a esta categoría de "palabras personales". No hay pronombres personales de tercera persona.

Los pronombres españoles él, ella, ello, ellos, ellas, le, la, lo, les, las, los, derivados de los demostrativos latinos, no son pronombres personales. Su significación no es más personal que la de los demostrativos este, ese, aquel, o que la de pronombres como alguno, otro o cualquiera. No pueden integrarse en el mismo parádigma que los pronombres personales ni por su manera de significar, ni por su forma ni por su comportamiento sintáctico. Junto con el artículo determinado, constituyen una clase de palabras referenciales que proporcionan valor de determinación a lo significado. Son semánticamente vacías y adquieren su valor designativo por referencia dentro de un contexto o de una situación determinada.

Como en latín, el español tiene un paradigma de reflexivos no personales, constituido por los pronombres sí, se y por el adverbio consigo. 